\title{
Hmong on the Move: Understanding Secondary Migration
}

\author{
Jac D. Bulk \\ University of Wisconsin-La Crosse
}

Between the time of first arrival of the Hmong refugees in 1975 and the mid-1990s, there has been much geographic movement of these new Americans. An initial pattern of Hmong residential dispersal throughout the American states has gradually transformed into a predominantly tri-state concentration (California, Wisconsin, and Minnesota). This highly distinctive resettlement pattern is the result of delicately balancing the most essential substance of Hmong tradition with pragmatic considerations such as job prospects (especially farming work), access to language and job training programs, extended family and clan obligations, changing federal policies for Refugee Cash Assistance (RCA), changing welfare eligibility regulations between the states (especially as it relates to AFDC-UP), climate and topographical considerations, and the like.

This paper details how the Hmong settlement profile within the United States has shifted between 1983 and the mid-1990s as a consequence of secondary migration. Quantitative comparison among Vietnamese, Cambodian, Laotian, and Thai settlement patterns throughout the United States is provided. The remainder of the paper attempts to explain why it is that 89 percent of all the Hmong in the United States currently reside in only three states. The broad conclusion reached is that the primary factors driving this dynamic pattern of $\mathrm{Hmong}$ resettlement are "economic betterment initiatives" and "extended family and clan obligations". The other factors cited above appear to have more derivative or secondary importance as influences upon Hmong resettlement. 


\section{Introduction}

As a nation of over fifty million foreign-born persons, the United States has experienced a wide variety of settlement patterns over the past two hundred years. Most typically, however, immigrants have followed the trail of "economic opportunity" often beginning with family relatives. Getting a start in a new society has always been and remains an awesome undertaking. Relatives provide vital resources, information, and social contacts through which one may first gain employment. Most immigrants initially settle in ethnic communities for this very reason. However, the Hmong, like other Southeast Asian refugees, begin arriving in the United States after 1975 without the benefit of any pre-established ethnic communities to move into. Furthermore, most Hmong did not come to America with the intent of seeking a new life but rather with the intent of preserving their old life in a new location. 1 This is the distinction that Jeremy Hein draws between a group having a predominantly "migrant orientation" versus a "minority orientation."2 In light of these differences, the settlement patterns of Hmong and other IndoChinese refugees may be anticipated to differ from the more traditional immigrant groups.

The secondary migration literature shows that Southeast Asian refugees fit into a singular pattern---substantial geographic dispersal, over one-half million Southeast Asian refugees (mostly Vietnamese, Chinese, Cambodians, Lowland Lao, and Highland Hmong) by 1982, followed by substantial secondary migration. This internal resettlement resulted in residential movement towards "the West and South and towards areas of higher refugee population." 3 The causes of this secondary migration stem from a variety of factors foremost of which are indicated to be the search for stable employment and reunion with relatives. 4 Regarding the first of these, Kelly notes that while the occupational qualifications of the Southeast Asian refugees (in terms of basic census categories) are similar to the general United States population, they tend to be have a difficult time finding jobs that pay above the minimum wage scale. Especially for the Vietnamese, this signifies downward mobility and tends to preserve dependence upon the US welfare system for economic survival. 5 Regarding the second of these, Mortland and Ledgerwood conclude that Southeast Asian resettlement ".. is part of a larger process: it is a voluntary act by the refugee that is profoundly influenced by traditional kinship relationships, patronage systems, [and] Southeast Asian mobility."6

At present there appears to be much general confusion and some public ill-feeling directed at the Hmong refugee population in the United States. Much of this is based upon myth and misinformation. One such mistaken notion is that the Hmong are a "nomadic people." Another such notion is that the Hmong lack a strong "work ethic" and as 
such prefer welfare dependence over economic self-sufficiency. Together, these mistaken notions suggest that American Hmong have become welfare nomads. As Congressman Mazzoli stated it on the record, "refugees have come to view welfare as an entitlement and quickly abandoned their cultural work ethic."7 As wrong as these notions are, they can easily be misconstrued from only a superficial acquaintance with the pertinent facts.

This paper will attempt to shed some light upon the phenomenon of Hmong secondary migration in the United States. The term secondary migration is used here to designate the geographic relocation of an ethnoracial group subsequent to its initial settlement. Since fully 89 percent of the Hmong in the United States (as of the 1990 Census) have become geographically concentrated in only three states---California, Wisconsin, and Minnesota---the question of "why this has happened" naturally arises, especially in light of the fact that there was no effort at all on the part of the federal refugee programs to encourage this type of concentrated settlement. Indeed, to the extent that there was any national refugee resettlement policy, it was to encourage a geographic dispersal of Southeast Asians so as to minimize social and economic impact upon local communities. This paper will attempt to clarify both "how and why" this contrary pattern of geographically concentrated Hmong family settlement came about and is continuing.

\section{Hmong Heritage}

In the first place any notion that the Hmong people are by tradition nomadic needs correction. While it is true that Hmong highland villages tend to move every ten years or so, this is not because the $\mathrm{Hmong}$ value "geographic mobility" per se as, for example, the Rom (Gypsies) or Bedouin traditionally have. On the contrary, the principal reasons that whole Hmong villages move are either that the nearby land has become infertile after years of slash and burn agriculture or to get away from an outbreak of disease believed to be caused by the presence of evil spirits, especially the phim nyuj vaim or "forest spirits".8 However, once the decision to move has been made by the village leaders, the new site is rarely more than two days walk from the old site. This is partly because new sites are often selected on the basis of favorable hunter and traveler reports from local community members. Also, by custom, it is considered "too risky" to allow children to sleep in the forest for more than one night at a time since traditional belief has it that when children sleep outside of the protective enclosure of the Hmong home, the phim nyuj vaim pose a very real threat to the child's health (this is referred to as "soul loss"). 9 This and numerous other more pragmatic considerations explain why Hmong are generally hesitant to resettle. Of course, this cultural fact may be obscured by showing the vast distances that Hmong people 
Ethnic Studies Review, Vol. 19, No. 1

have journeyed across the Asian continent (from Northern China to Central China to Southern China to Laos) over the past several millennia. 10 Nonetheless, these major geographic movements of Hmong population have been infrequent, highly sporadic, and typically driven by Han military force. In short, the Hmong are not properly described as "nomadic," at least not by any standard definition. 11

\section{Hmong Work Ethic}

Likewise, any notion that Hmong people are lazy or deficient in a "work ethic" flies in the face of the facts. Indeed, it is not uncommon to hear adult Hmong say that mainstream Americans are "lazy" by comparison to themselves. As swidden (slash and burn) farmers, the traditional Hmong lifestyle was one of hard physical labor from sunrise to sunset. They grew all their own food supplies, hunted wild game, built their own houses and furniture, and manufactured their own clothing, jewelry, and musical instruments. The misconception of the Hmong as being "lazy" apparently derives from the observation that many American $\mathrm{Hmong}$ are currently unemployed and receiving welfare assistance. From this it is inferred that "these people" must not place a high value on "working." However, this has little or nothing to do with Hmong values towards work. 12 Most adult Hmong who are currently without jobs lack English language fluency, lack background in formal education, and do not possess any marketable trade skills. Beyond this, many of the elder Hmong adults no longer feel any obligation to work as their children are now expected to support their parents in their old age as has always been the Hmong tradition. None of this, however, demonstrates any loss of a work ethic. Those Hmong who have found employment (mostly in factory work) are recognized to be reliable, hard workers. Likewise, their children are widely recognized to be hard-working students reflecting their community's normative pressures to excel in their labors.

\section{Clan Obligations}

One vital aspect of Hmong heritage is their clan system of social organization. There are a total of $22 \mathrm{Hmong}$ clans of which only 14 are common in the United States---Chang, Hang, Her, Khang, Kong, Kue, Lee, Lor, Moua, Thao, Vang, Vue, Xiong, and Yang. 13 Much of Hmong identity a s well as social obligation is rooted in the person's clan affiliation. Most significantly, as relates to the thesis of this paper, where a person resides is greatly influenced by one's clan. Most Hmong villages in Laos, for example, are almost entirely composed of members of the same clan. Upon birth a child always becomes a member of his or her father's clan. And upon marriage the wife always joins her husband's clan while still retaining her birth name (in other words, her father's clan name). 
After marriage, the husband also becomes a sort of in-law member of his wife's clan and a pattern of mutual assistance between the spousal clan groups will be encouraged.

The importance of the clan in Hmong social organization is reflected in the fact that persons of the same clan (xeem) are considered brothers and sisters and Hmong who travel may anticipate being given food and lodging as well as other assistance by their clan brothers and sisters despite having never met them before. This clan support extends across the nation and across the world and there are approximately 10 million Hmong in the world today. Another indicator of the central role of the clan in Hmong life is the custom that a person cannot die in the household of another Hmong clan. And when a Hmong man dies his clan is obligated to care for his surviving wife and children. The general importance of the clan to the Hmong social community is reflected in most aspects of daily living including conflict resolution. Clan leaders, when needed, will be called upon to help resolve marital disputes, assist in disciplinary problems involving children, and even give advice about possible family relocation. It is noteworthy that the social importance of the clan for the Hmong refugee stands in sharp contrast to the comparably lesser role that it plays in the social life of the Vietnamese refugee.14

\section{Extended Family Obligations}

Obligations to the extended family also influence the settlement patterns of Hmong who are, by tradition, patrilineal. This is in sharpest contrast to the Cambodians and Lowland Lao who follow decidedly more bilateral lineage systems. The indirect role that family obligations play in Hmong secondary migration cannot be overstated and should not be regarded as common to all Southeast Asian peoples. Hmong tradition has always been for grandparents, uncles, aunts, parents, and children to live within the same household. While this is often difficult if not impossible to accommodate in the United States, members of the extended family still attempt to reside in close proximity to one another. In short, there is a normative family reunification that impacts all members of the extended family unit. Beyond this there are a myriad of social obligations that serve to draw the Hmong extended family together. Foremost of these obligations is to care for and respect one's elders. The adage---"Elders see the sky first"---indicates the high status and esteem accorded to those family members with the most years of life experience. And so while young Hmong may venture out in search of new lands and new opportunities, they are nonetheless bound by a whole network of family support obligations which cannot be fulfilled without residential proximity to one's extended family. For example, when a Hmong elder dies, it is a family obligation to arrange the ceremony in which a Hmong shaman will guide the soul of the deceased to the spirit world. 


\section{Hmong Migration to and Settlement Patterns within the United States}

Hmong migration to the United States commences, by no coincidence, with the fall of Saigon to communist-allied military forces in April of 1975. The first Hmong refugees were placed with non-Hmong sponsors in a geographically dispersed pattern across the US mainland. However, for somewhat unknown reasons this resulted in placements that were more concentrated in the northern states than in the southern ones. As stated in an official government report of 1985, "The original distribution of the Highland Lao in the United States had more to do with the operations of the voluntary resettlement agencies (volags) than with the wishes of the refugees." 15 Likewise, this distribution of the Highland Lao had little to do with regional employment opportunity as reflected by the fact that the national unemployment rate was generally lower than the regional unemployment rate where most Highland Lao were initially settled.16 While only a few thousand Hmong were admitted to the United States between 1975 and 1978, over ten thousand were admitted in 1979 , and another 27,000 arrived in 1980---by farthe peak year of Hmong refugee admissions up to the present time. After a hiatus in these 1980 admissions, some additional 30,000 Hmong arrived between 1987 and 1990.17 And most recently between 1991 and 1994 another 26,000 Hmong refugees were admitted to the United States signifying what is in all likelihood the end of this stream of refugees considering the imminent closing of the Thai refugee camps by September of 1997.18 From the $4,500 \mathrm{Hmong}$ remaining in the Thai camps as of 1996, 3,500 are now forecast to be reunited with relatives in Minnesota, Wisconsin, and other States when these camps are finally closed.

The settlement patterns that Hmong exhibited were not uniform reflecting an inconsistent set of federal and state policies compounded further by Hmong "economic explorations" and subsequent attempts to promote family reunification. In the first years of Hmong settlement in the United States, the refugees had little to say about their geographic placement. Instead, these initial placements were controlled by the voluntary resettlement agencies (volags) which were private non-profit organizations that were funded largely by the US State Department. These volags were largely New York-based and Atlantic-facing. They relied heavily upon the benevolence of Catholic Charities and other church organizations willing to assist in the resettlement of single Hmong families. Not surprisingly this resulted in a general pattern of geographic dispersal. However, by the early 80 s, the newly-settled Hmong families began serving as sponsors for incoming Hmong refugees, especially fellow clan members. This, in combination with the first secondary migration of Hmong refugees, resulted in "a strong movement of Hmong and other Highland Lao refugees from elsewhere in the nation to the 
Central Valley of California."19

This influx of Highland Lao refugee population into California--90 percent of which was Hmong---spurred immediate federal action to deflect this secondary migration. The purpose of this deliberate intervention was to promote Highland Lao community stability outside of the State of California. The specific action taken was given the name Highland Lao Initiative (HLI) and it was directed at approximately 32,000 Highland Lao refugees located in some 44 communities within the United States but outside of California. The funding agency of this federal program was the Office of Refugee Resettlement (ORR) of the U. S. Department of Health and Human Services. At this time about 60 percent of the Highland Lao refugees were concentrated in California and Minnesota and the HLI targeted the remaining 40 percent. The population estimates and locations of the targeted sites are provided in Table 1. As may be observed from this table, the HLI-funded sites were, in fact, geographically scattered. The basic strategy of the HLI was to make these particular settlement areas more attractive to the Highland Lao refugees through selective funding of special services needed by these refugees. Specifically, the funded services included outreach (for example, interpretation, transportation, and advocacy services for individual Hmong), job placement, on-the-job training, vocational training, craft development, English as a Second Language (ESL), farm and gardening assistance, child care support, and some business development help.20 Examining the short-term impact of these single year federal funding initiatives (some of which were continued and some not), reveals that secondary migration away from the non-Wisconsin sites proceeded slowly. Specifically, there was a net population decline in these sites of only 3 percent (from 15,302 in the Fall of 1983 to 14,866 in the Fall of 1984) whereas the Wisconsin sites simultaneously showed a sharp 37 percent increase (from 2,882 to 3,936).21 When we measure the longer-term impact of this initiative by looking at the geographic distribution of the Hmong in 1990, it appears that the initiative was largely successful in deflecting secondary migration away from California. Whereas the Hmong in California represented 52 percent of the total American Hmong population in 1990, this contrasts with an approximate figure of 51 percent for 1983, the year the HLI began.22

However, this relative stability in the aggregate Hmong population in the State of California between 1983 and 1990 should not obscure the large amount of secondary migration that coincided with this period. As an inspection of Table 2 makes plain, there was an aggregate Hmong population loss of some 10,994 persons from 20 states between 1983 and 1990. The largest of these population losses occurred in the states of Illinois, Rhode Island, and Utah which together account for 42 percent of this Hmong out-migration. 
Ethnic Studies Review, Vol. 19, No. 1

Table 1. Estimated Highland Lao Population in HLI-Funded Sites (May, 1983)

\begin{tabular}{|c|c|c|c|c|c|}
\hline HLI Site & Hmong & Iu Mien & Lao Lue & Lao Theung & Total \\
\hline Hartford, CT & 212 & & & & 212 \\
\hline Fitchburg, MA & 220 & & & & 220 \\
\hline Providence, RI & 2,300 & & & & 2,300 \\
\hline Syracuse, NY & 160 & & & & 160 \\
\hline Philadelphia, PA & 1,200 & & & & 1,200 \\
\hline Decatur, GA & 500 & & & & 500 \\
\hline Marion-Morgantown, NC & 450 & & & & 450 \\
\hline Memphis, TN & 450 & & & & 450 \\
\hline Montgomery, AL & & 100 & & & 100 \\
\hline Selma, AL & 100 & & & & 100 \\
\hline Akron, $\mathrm{OH}$ & 250 & & & & 250 \\
\hline Appleton, WI & 950 & & & & 950 \\
\hline Chicago, IL & 648 & & & & 648 \\
\hline Columbus, $\mathrm{OH}$ & 151 & & & & 151 \\
\hline Danville-Decatur, IL & 235 & & & & 235 \\
\hline Detroit, MI & 770 & & & & 770 \\
\hline Dixon, IL & 278 & & & & 278 \\
\hline Eau Claire, WI & 500 & & & & 500 \\
\hline Green Bay, WI & 493 & & & & 493 \\
\hline Kankakee, IL & 265 & & & & 265 \\
\hline La Crosse, WI & 600 & & & & 600 \\
\hline Lansing, MI & 510 & & & & 510 \\
\hline Milwaukee, WI & 1,000 & & & & 1,000 \\
\hline Minneapolis, MN & 8,730 & & & & 8,730 \\
\hline Moline-Rock Island, IL & 180 & & & & 180 \\
\hline Rochelle-De Kalb, IL & 78 & & & & 78 \\
\hline Saginaw, MI & 291 & & & & 291 \\
\hline Sheboygan, WI & 700 & & & & 700 \\
\hline Toledo, $\mathrm{OH}$ & 350 & & & & 350 \\
\hline Wausau, WI & 470 & & & & 470 \\
\hline Wheaton, IL & 370 & & & & 370 \\
\hline Ft. Smith, AK & 300 & & & & 300 \\
\hline Tulsa, OK & 500 & & & & 500 \\
\hline Billings, MT & 150 & & & & 150 \\
\hline Denver, CO & 1,750 & & & & 1,750 \\
\hline Des Moines, LA & 663 & & & & 663 \\
\hline Kansas City, KS & 800 & & & & 800 \\
\hline Missoula, MT & 307 & & & & 307 \\
\hline Omaha, NE & 325 & & & & 325 \\
\hline Salt Lake City, UT & 1,500 & & & & 1,500 \\
\hline Portland, OR & 970 & 1,300 & & & 2,270 \\
\hline Salem, OR & 190 & 100 & & & $290^{\circ}$ \\
\hline Seattle, WA & 700 & 550 & 150 & 230 & 1,630 \\
\hline Spokane, WA & 400 & 20 & & & $\$ 20$ \\
\hline
\end{tabular}


Table 2. Hmong Settlement and Movement Patterns by State: 1983 to 1988 to 1990

\begin{tabular}{|c|c|c|c|c|c|}
\hline State & $\begin{array}{l}\text { Primary } \\
\text { Location" }\end{array}$ & $\begin{array}{l}983 \text { State } \\
\text { opulation }\end{array}$ & $\begin{array}{l}1988 \text { State } \\
\text { Population }^{b}\end{array}$ & $\begin{array}{l}1990 \text { State } \\
\text { Population }^{\mathrm{b}}\end{array}$ & $\begin{array}{l}\text { Net State Population } \\
\text { Change: } 1983 \text { to } 1990\end{array}$ \\
\hline $\mathbf{A L}$ & Selma & 100 & $\mathbf{0}$ & 8 & -92 \\
\hline $\mathbf{A R}$ & Fort Smith & 339 & 46 & 23 & -316 \\
\hline $\mathrm{CO}$ & Denver & 1,750 & 1,300 & 1,202 & -548 \\
\hline GA & Atlanta & 500 & 823 & 320 & -180 \\
\hline IL & Chicago & 2,503 & 702 & 433 & $-1,801$ \\
\hline IN & Indianapolis & 120 & 65 & 57 & -63 \\
\hline IA & Des Moines & 911 & 403 & 227 & -684 \\
\hline KS & Kansas City & 800 & 600 & 603 & -187 \\
\hline MT & Missoula & 457 & 390 & 146 & -311 \\
\hline NE & Omaha & 325 & 366 & 78 & -403 \\
\hline OH & Toledo & 654 & 455 & 253 & -401 \\
\hline OK & Tulsa & 624 & 300 & 207 & -417 \\
\hline OR & Portland & 1,260 & 1,130 & 438 & -822 \\
\hline PA & Philadelphia & 1,200 & 750 & 358 & -842 \\
\hline $\mathbf{R I}$ & Providence & 2,300 & 2,178 & 884 & $-1,416$ \\
\hline TN & Memphis & 450 & 105 & 79 & -371 \\
\hline TX & Dallas/Ft. Worth & 350 & 395 & 176 & -219 \\
\hline UT & Salt Lake City & 1,500 & 168 & 105 & $-1,395$ \\
\hline WA & Seattle & 1,100 & 1,182 & 741 & -359 \\
\hline $\mathbf{C A}$ & State Total & 30,000 & 58,976 & 46,892 & $+16,892$ \\
\hline MA & Fitchburg & 220 & 525 & 248 & +28 \\
\hline MI & Detroit & 1,601 & 2,610 & 2,257 & +656 \\
\hline MN & Minneapolis/St. Paul & I 8,840 & 13,700 & 16,833 & $+7,993$ \\
\hline $\mathbf{N J}$ & Bound Brook & $\mathbf{0}$ & 70 & 25 & +25 \\
\hline NY & Syracuse & 160 & 300 & 165 & +5 \\
\hline NC & Morganton & 450 & 818 & 708 & +258 \\
\hline SC & Spartanburg & 75 & 84 & 76 & +1 \\
\hline SD & Sioux Falls & 0 & 22 & 27 & +27 \\
\hline VA & Sterling & 0 & 34 & 7 & +7 \\
\hline \multirow[t]{12}{*}{ WI } & State Total & 4,713 & 16,106 & $18,970^{c}$ & $+14,257$ \\
\hline & Appleton & 950 & 1,850 & 2,000 & $+1,050$ \\
\hline & Eau Claire & 500 & 1,859 & 2,160 & $+1,160$ \\
\hline & Green Bay & 493 & 1,572 & 2,300 & +1807 \\
\hline & La Crosse & 600 & 1,898 & 2,390 & $+1,790$ \\
\hline & Madison & 0 & 650 & 750 & +750 \\
\hline & Manitowoc & 0 & 800 & 1,150 & $+1,150$ \\
\hline & Milwaukee & 1,000 & 3,000 & 3,250 & $+2,250$ \\
\hline & Oshkosh & $\mathbf{0}$ & 658 & 930 & +930 \\
\hline & Sheboygan & 700 & 1,178 & 1,800 & $+1,100$ \\
\hline & Wausau & 750 & 1,800 & 2,040 & $+1,290$ \\
\hline & Other Places & 0 & 841 & 1,030 & $+1,030$ \\
\hline
\end{tabular}

- Primary Location refers to the city within the State with the largest Hmong population in 1983.

b These figures represent the State totals and do, in some instances, include Hmong from locations other than the one cited as the primary location.

' These figures for the State of Wisconsin are MAA estimates and are about $10 \%$ higher than Census reports. 
In sharp contrast to this pattern, Table 2 also indicates that 11 states experienced an aggregate Hmong population increase of 54,456 between 1983 and 1990. And in this group, the three states of California, Minnesota, and Wisconsin account for 72 percent of the aggregate increase in Hmong population. In short, the data give evidence of quite substantial amounts of $\mathrm{Hmong}$ population redistribution over a relatively short span of time. As relatively little of this change might be accounted for in terms of differential fertility, we may safely conclude that it is principally the result of secondary migration trends supplemented, to some extent, by new refugee arrivals who would predictably tend to follow the movement patterns of their sponsoring families.

Other insights into Hmong migration and settlement patterns are provided when we look at the geographic distribution of various Southeast Asian groups by the time of the 1990 Census. One fact is readily apparent; namely, California remains the State of preeminent attraction to most Asian immigrant groups in America. The percentage of the Southeast Asian aggregate group populations in California in 1990 was as follows:

$\begin{array}{lll}\text { Hmong } & 52 \text { percent } \\ \text { Cambodian } & 46 \text { percent } \\ \text { Vietnamese } & 45.5 \text { percent } \\ \text { Laotian } & 39 \text { percent } \\ \text { Thai } & 35 \text { percent }\end{array}$

On the one hand, this reflects the fact that California is, by far, the largest magnet state for legal immigrants in the United States attracting 40 percent of the 1,827,167 people granted legal permanent residence in this nation in 1991. On the other hand, it also reflects a long established ethnic tradition of Asian immigration preference for the West Coast region of America.23 This also reflects a strong motivation of these groups to form ethnic enclave communities which may facilitate their adaptation to the mainstream society without having to lose touch with the fundamentals of their ethnic traditions. So even within the State of California we tend to find that these groups are concentrated within certain counties to the exclusion of others (for example, Fresno County, by itself, accounts for about 40 percent of all Hmong persons in the State as of the 1990 census).24 The four California counties of Fresno, Merced, Sacramento, and San Joaquin together account for over 74 percent of the in-state Hmong population.

Further evidence of this general tendency towards ethnic concentration is provided when we combine the populations of the three states most heavily settled by each of the Southeast Asian groups represented in Table 3. And of these groups the Hmong are the most geographically concentrated. 
Table 3. The Geographic Distribution of Select IndoChinese Populations by State: 1990

\begin{tabular}{|c|c|c|c|c|c|}
\hline & Hmong & Vietnamese & Cambodian & Laotian & Thai \\
\hline Alabama & 8 & 2,274 & 427 & 799 & 526 \\
\hline Alaska & 1 & 582 & 50 & 226 & 369 \\
\hline Arizona & 9 & 5,239 & 787 & 855 & 1,381 \\
\hline Arkansas & 23 & 2,348 & 28 & 1,982 & 248 \\
\hline California & 46,892 & 280,223 & 68,190 & 58,058 & 32,064 \\
\hline Connecticut & 45 & 4,085 & 1,754 & 2,989 & 529 \\
\hline Delaware & $\mathbf{0}$ & 348 & 23 & 107 & 142 \\
\hline District of Columbia & 0 & 747 & 55 & 51 & 212 \\
\hline Florida & 7 & 16,346 & 1,617 & 2,423 & 4,457 \\
\hline Georgia & 320 & 7,801 & 2,140 & 3,511 & 1,608 \\
\hline Hawaii & 6 & 5,468 & 119 & 1,677 & 1,220 \\
\hline Idaho & $\mathbf{0}$ & 600 & 66 & 482 & 188 \\
\hline Illinois & 433 & 10,309 & 3,026 & 4,985 & 5,180 \\
\hline Indiana & 57 & 2,467 & 412 & 674 & 654 \\
\hline Iowa & 227 & 2,882 & 611 & 3,374 & 921 \\
\hline Kansas & 613 & 6,577 & 550 & 2,315 & 675 \\
\hline Kentucky & 1 & 1,505 & 231 & 260 & 403 \\
\hline Louisiana & 1 & 17,598 & 308 & 1,024 & 704 \\
\hline Maine & $\mathbf{0}$ & 642 & 767 & 101 & 113 \\
\hline Maryland & 1 & 8,862 & 1,768 & 767 & 2,578 \\
\hline Massachusetts & 248 & 15,449 & 14,050 & 3,985 & 1,424 \\
\hline Michigan & 2,257 & 6,117 & 874 & 2,190 & 1,284 \\
\hline Minnesota & 16,833 & 9,387 & c3,858 & 6,381 & 576 \\
\hline Mississippi & 7 & 3,815 & 24 & 59 & 239 \\
\hline Missouri & 13 & 4,380 & 628 & 654 & 1,088 \\
\hline Montana & 146 & 159 & 4 & 185 & 107 \\
\hline Nebraska & 78 & 1,806 & 98 & 810 & 343 \\
\hline Nevada & 24 & 1,934 & 244 & 804 & 1,823 \\
\hline New Hampshire & 2 & 1,501 & 553 & 380 & 233 \\
\hline New Jersey & 25 & 7,330 & 475 & 478 & 1,758 \\
\hline New Mexico & 0 & 1,485 & 55 & 522 & 440 \\
\hline New York & 165 & 15,555 & 3,646 & 3,253 & 6,230 \\
\hline North Carolina & 708 & 5,211 & 1,367 & 2,048 & 1,183 \\
\hline North Dakota & 2 & 281 & 54 & 54 & 114 \\
\hline Ohio & 253 & 4,964 & 2,213 & 2,578 & 1,515 \\
\hline Oklahoma & 207 & 7,320 & 307 & 902 & 942 \\
\hline Oregon & 438 & 9,088 & 2,101 & 3,262 & 876 \\
\hline Pennsylvania & 358 & 15,887 & 5,495 & 2,048 & 1,293 \\
\hline Rhode Island & 884 & 772 & 3,655 & 2,579 & 141 \\
\hline South Carolina & 76 & 1,752 & 239 & 598 & 565 \\
\hline South Dakota & 27 & 268 & 76 & 138 & 129 \\
\hline Tennessee & 79 & 2,062 & 942 & 2,772 & 586 \\
\hline Texas & 176 & 69,634 & 5,887 & 9,332 & 5,816 \\
\hline Utah & 105 & 2,797 & 997 & 1,774 & 617 \\
\hline Vermont & 3 & 236 & 58 & 115 & 80 \\
\hline Virginia & 7 & 20,693 & 3,889 & 2,589 & 3,312 \\
\hline Washington & 741 & 18,696 & 11,096 & 6,191 & 2,386 \\
\hline West Virginia & 0 & 184 & 27 & 38 & 226 \\
\hline Wisconsin & 16,373 & 2,494 & 521 & 3,622 & 502 \\
\hline Wyoming & 0 & 124 & 6 & 17 & 91 \\
\hline TOTALS & $\overline{90,081}$ & 615,494 & 147,688 & 149,014 & 91,275 \\
\hline
\end{tabular}


Ethnic Studies Review, Vol. 19, No. 1

Hmong
Cambodian
Vietnamese
Laotian
Thai

89 percent in California, Wisconsin, and Minnesota

63 percent in California, Massachusetts, and Washington

60 percent in California, Texas, and Virginia 49.5 percent in California, Texas, and Minnesota 48 percent in California, New York, and Texas

The Hmong are distinguished from the other groups represented in Table 3 by their almost complete absence from no fewer than 20 states: Alabama, Alaska, Arizona, Delaware, District of Columbia, Florida, Hawaii, Idaho, Kentucky, Louisiana, Maine, Maryland, Mississippi, New Hampshire, New Mexico, North Dakota, Vermont, Virginia, West Virginia, and Wyoming each have fewer than ten resident Hmong persons. And another nine states---Arkansas, Connecticut, Indiana, Missouri, Nebraska, Nevada, South Carolina, South Dakota, and Tennessee--each have fewer than one hundred resident Hmong. None of the other groups display any comparable level of geographic compression.

\section{Explaining Hmong Settlement Patterns in America}

There appear to be two primary forces which have been driving the Hmong resettlement patterns---first, prospects for both immediate and long-term economic betterment and second, extended family and clan obligations. Adding on to these factors, secondary influences on $\mathrm{Hmong}$ resettlement include prospects for farming, access to job training and ESL programs, access to short-term welfare support (mainly AFDC), favorable climate and topography, and avoidance of large congested metropolitan areas. In short, this analysis suggests that the Hmong in America are attempting to make the best out of a most difficult circumstance by attempting to recover their accustomed economic selfsufficiency without an undue abandonment of their familial and clan obligations which are at the core of their cultural identity.

\section{Initiatives Towards Economic Betterment}

The various federal site reports on Hmong resettlement provide a rich record of how central the economic betterment motive is to their secondary migration patterns. And yet this does not mean that the Hmong uncritically accept the first job offer they get. Some Hmong actually leave jobs in search of language programs and/or vocational training opportunities which carry hopes of better future employment. To illustrate this, the cases of Hmong migration to and subsequently away from Fort Smith, Arkansas and Portland, Oregon will be briefly examined. Fort Smith will be discussed first as a case of planned secondary migration 
away from Southern California (one of the Hmong magnet states). Subsequently, the Portland, Oregon case will be discussed to highlight other factors (but especially the role of state and federal welfare policies) that jointly serve to influence Hmong secondary migration.

\section{The Fort Smith Case}

The first Hmong families to move to Fort Smith arrived in November, 1979 and were soon followed by others who formed a cohesive Hmong community of 296 by 1983 . Surprisingly, "as many as eighty percent of the employable adults who went to Fort Smith were not on public assistance prior to their move but left steady, full-time jobs in order to go." 25 The oddity of this resettlement effort is compounded by realizing that this move meant leaving rather than rejoining relatives. This puzzling migration of Hmong into an uncharted region of the United States is best understood as an outgrowth of Hmong planning for longterm economic self-sufficiency. The site report indicates that, rightly or wrongly, the Hmong leaders believed that by relocating in Fort Smith a number of social and economic advantages would accrue; namely, it was believed that there were good prospects for many manufacturing jobs, that there were reasonable prospects for small farming, that it was feasible for Hmong to pursue self-employment through small business ventures, that the cost of living in Arkansas was less than most other states, and in general that their chances of becoming independent of welfare and uncertain employment were improved. In short, the whole Fort Smith community relocation was premised upon prospects of economic betterment with less government interference stemming from welfare dependence. It is noteworthy as well that this "pioneer community" attracted Hmong families from various parts of California, from Montana (Missoula), from Illinois, from Oklahoma, from Minnesota (St. Paul), and from Utah (Salt Lake City).

However, in spite of an auspicious start, economic difficulties soon arose in a faltering state economy. Many jobs were lost and the dreams of becoming self-employed by acquiring and farming land, raising livestock, and creating business enterprises quickly faded. Instead, many Hmong families found themselves unemployed, without AFDC eligibility, and with mounting hospital bills incurred as a result of childbirth and illnesses. By 1988 , there were only $46 \mathrm{Hmong}$ in the State of Arkansas and by 1990 only 23 . The Hmong, in this scenario, were clearly motivated to move into and later out of the State of Arkansas primarily by employment prospects and the likelihood of being able to farm for a living. And today there is a similar movement of Hmong into the State of South Carolina seeking an agricultural lifestyle where economic selfsufficiency might be possible without the necessity of welfare dependence and where traditional family and clan obligations might more 
easily be observed.

\section{The Portland Case}

The Hmong settlement in and subsequent mass migration out of Portland, Oregon begins in 1976 and extends over the decade of the 1980s. The first Hmong to arrive in Portland in 1976 were among the earliest refugee arrivals of this group in the United States. As was customary at this time, these refugees were handled by voluntary agencies such as the Catholic Resettlement Office of Catholic Charities who identified sponsors to assist these families in the initial adjustment to American society. However, by 1981 , Hmong families already settled in Portland began assuming the major role of sponsors for new arrivals from the refugee camps of Thailand.26 These new arrivals plus added secondary migration swelled the size of the Portland Hmong community to a peak of 4,500 by December, 1981 . However, an exodus migration to the Central San Joaquin Valley of California began in the Fall of 1981 and continued through the Spring of 1983 dropping the Hmong population in Portland to one-fourth its prior size (1,068 persons). And since then the Hmong population in the entire State of Oregon has dropped to just 438 persons. In order to account for this 90 percent decimation of the Portland Hmong community in less than a decade, we must consider both the push and pull factors operative in this State. Among the variety of pull factors were the dream of small farming opportunities in California, access to more English language training programs in California, the desire to promote family reunification, and access to family welfare programs in California.

Foremost among the push factors were the changing federal policies defining welfare eligibility for the Hmong refugees. As many Hmong arrived in the US without either English speaking aptitude or marketable job skills, the need for special training and/or temporary cash assistance was critical. And, since most states had "family composition" restrictions which excluded two parent Hmong families from AFDC eligibility, the federal Government enacted various bills between 1975 and 1992 extending cash assistance to needy IndoChinese refugees. This commenced with the IndoChina Migration and Assistance Act of 1975 and was followed by the IndoChina Migration and Refugee Assistance Act of 1977. These bills were followed by the well-known Refugee Act of 1980 which removed "family composition" welfare requirements and created the Refugee Cash Assistance (RCA) program. This important program provided for the federal Government to pay 100 percent of the public assistance costs of each arriving IndoChinese refugee over a three year period. However, beginning in 1982 federal subsidy of RCA was diminished to 18 months and was then reduced to only 8 months in 1992. The consequence of this vanishing federal welfare 
subsidy for IndoChinese refugees was to elevate the importance of state welfare policies. And Oregon was one of the twenty-four states that restricted AFDC eligibility to single parent families. 27 Since Hmong are a very family-oriented group with an extremely low divorce rate, relatively few Hmong families in Portland met the single parent AFDC requirement, thereby intensifying the economic pressure to resettle.

By contrast, California extends AFDC eligibility to needy families without regard to whether or not both parents are living together. In addition, California and Wisconsin are among the few states who take the generous approach in interpreting the rule that recipients prove that they have worked for six of the previous thirteen quarters in order to be eligible for welfare support.28 As a consequence, welfare eligibility policies resulted in a strong motive force to leave Oregon and enter neighboring California.29 This is in fact the locality to which most of the Portland Hmong did migrate.

It is of telling significance that of the 1,068 Hmong in Portland in 1988, some 87 percent of the families there were economically selfsufficient. This is in sharp contrast to the 28 percent of the Hmong families in California that were self-sufficient as of this same date. While there is no ignoring the fact that the three States attracting the greatest Hmong population growth between 1983 and 1990 are the same states with the highest percentage of families on welfare, this should not be interpreted to mean that Hmong prefer welfare dependency over economic selfsufficiency. On the contrary, as the Portland case indicates, the Hmong are inclined to migrate mostly out of economic necessity. Those Hmong families who have been successful in earning enough money to get off welfare subsidy have for the most part chosen not to migrate even when many kinsmen from the same locality have moved on in search of better employment prospects. Good evidence of this is provided by comparing the average economic self-sufficiency of the Hmong communities identified as positive-growth and those identified as negative-growth in Table 2. The mean economic self-sufficiency of the families in the negative-growth Hmong communities is 84 percent while the families in the positive-growth Hmong communities have a mean economic selfsufficiency of just 30 percent. The number of Hmong families in this former group was 1,594 while the number of Hmong families in the latter group was 15,217. It appears that Hmong families without adequate jobs or adequate job prospects move on while those who have established some measure of economic viability remain. However, since most Hmong who succeed in becoming economically self-sufficient generally do not own businesses, their capacity to employ fellow Hmong or to sustain large numbers of dependents is very limited. This fact, in turn, accounts for much of the ongoing secondary migration. And the states most likely to attract the less fortunate job-seeking Hmong are California, Wisconsin, and Minnesota. The simple explanation for this is 
that these states have emerged as the "most friendly" towards the Hmong in terms of their AFDC policies and, equally important, in terms of their support services relating to language training and job placement. For example, Wisconsin and Minnesota were two of the five states which elected to participate in the Key States Initiative (KSI) in 1987. This is a federally funded, voluntary program that supports a set of coordinated actions to increase self-sufficiency of Hmong and other severely disadvantaged refugees. The essence of the KSI approach is to remove the most critical barriers to family self-sufficiency on a group-specific basis. 30

\section{Extended Family and Clan Obligations}

The fact that the large majority of the Hmong family units in the United States are not yet economically self-sufficient means that there are strong pressures on these families. And since some states have deliberately made programmatic efforts to meet the needs of the Hmong refugees, this has produced a certain gravitational pull towards either California, Wisconsin, or Minnesota. And this is where Hmong clan, family, and ancestral obligations enter as another powerful factor in explaining the group's resettlement patterns. 31

As unemployed adult Hmong, who are still the majority, gravitate towards the states with the most refugee support services and the highest monthly AFDC cash payments, family reunification pressures tend to attract others who may be only marginally employed in other regions. As stated in one of the federal Hmong resettlement studies, "the attraction of family reunification and the desire of the population to live together seem to become an increasingly irresistible force, so that in places like the Central Valley of California, for example, migration continues even in the face of massive unemployment, high welfare dependence and inadequately funded social services." 32 Of course, this same dynamic might work to pull Hmong out of the magnet states if a secure employment anchor were to be established elsewhere. However, given the large percentage of Hmong elders without English language fluency or transferable job skills and given the substantial amount of transgenerational family obligation (often referred to as "filial piety") that is characteristic of Hmong tradition, geographically scattered Hmong individuals become subject to a kind of cultural gravity that pulls them back together into clan groupings. The reality of this is best visualized in Table 3 where the geographic spread of the Hmong across states can be seen as far less than for the Vietnamese, Cambodian, Laotian, or Thai groups. Recall that there were 20 states with fewer than ten resident Hmong persons.

And not unlike some ethnic groups in the United States but far more so than average, marriage outside the Hmong group is strongly 
discouraged. This is yet another indication of how traditional custom operates upon the Hmong to direct their geographic movements towards areas where other Hmong are already settled.33 Unlike mainstream Americans affiliated with nuclear family structures and relatively small numbers of close relatives, Hmong are affiliated with clans which recognize a measure of obligation in helping their members to adjust to their new society. While limited resources generally curtail the ability of Hmong to accommodate moves of large numbers of clan relatives to a given locality, the Hmong are still relatively free to change residence on a temporary or provisional basis. This tendency may lead to double counting of Hmong residents as they decide which residential locality is most promising for the future welfare of one's immediate family. Of course, it is true that Hmong ethnogenesis is part of a dialectical process through which ethnically negotiated adaptation to mainstream custom and law occurs. As such, the Hmong clan system of social organization continues, in its own right, to influence the patterns of residential movement exhibited by Hmong in the United States today. This influence extends to the traditional customs through which Hmong leaders decide when and to where it is appropriate to move their village. Hmong resettlement tendencies must be viewed in the context of a cultural heritage that subordinates the needs of the individual to those of the family (elders especially) and the clan. And it is in this larger context that the welfare needs of the Hmong elderly have a greater impact over the resettlement freedoms of the young than we realize. The conflict between Hmong and mainstream American welfare traditions is well expressed by Jeremy Hein as follows: "In the American mode of incorporation, refugees are expected to use state resources as individuals or households, not as members of an extended kin group or an ethnic community. Refugees' resist the social welfare system's individualization of the adaptation process and turn to their kin and ethnic networks for a collective response. Use of state resources is an element of their collective adaptation, and the result is a constant conflict between refugees and refugee managers." 34

\section{Conclusions}

While the patterns of secondary migration exhibited by the Hmong refugees since 1975 are superficially baffling---showing as they do greatest population growth in those regions with the highest rates of unemployment and welfare dependence---there is nonetheless an explanation for this that does not in any way imply a deflated "work ethic" in this community. This explanation of Hmong residential movements focuses on the reconciliation of the twin goals of economic selfsufficiency, complicated by changing federal and state welfare policies, and the best efforts of the Hmong to accommodate their traditional obligations to family, 
clan, and ancestors. In some instances, such as the previously described resettlement in Fort Smith, Arkansas, prospects for economic selfsufficiency were so strong as to risk resettling a Hmong community in a state with very few refugee support services and strict welfare policies which rendered most Hmong ineligible. The site records indicate that those Hmong families around the country who have been successful in finding jobs and who have become economically self-sufficient are not so inclined toward movement as are those without such good fortune.

Nonetheless, a complete explanation of Hmong resettlement patterns requires that attention also be paid to the vital role that Hmong family, clan, and ancestral obligations play. Hmong are not "rugged individualists" in the mainstream American tradition who are free to migrate wherever they might choose without giving serious consideration to their community obligations. This imported cultural reality may be seen as alternately a strength and a liability in the move towards Hmong economic self-sufficiency in the United States. On the positive side, the Hmong community provides a solid anchor for pooling social and economic resources and supporting some persons who might not otherwise be capable of acquiring gainful employment. On the negative side, social ties to family and clan may serve to constrain the ready mobility of younger and more educated Hmong individuals.

And finally, beyond these core factors underlying Hmong secondary migration patterns, there are also a variety of secondary influences at work. For example, the Hmong tradition of farming continues to motivate many families to move into regions that they believe offer prospects of small farming. 35 Another strong influence upon Hmong migration has been access to job training, job placement services, and English language programs (such as ESL). In addition, the Hmong drive towards economic self-sufficiency cannot be divorced from the matter of changing federal and state welfare policies. The net impact of these changes has been to shift the welfare burden from the federal to the state level and in the process has resulted in some states being much more attractive to and supportive of Hmong social service needs.

Some lesser consideration has been given to the climate and topography of a region. Prior to their arrival in the United States few Hmong had any experience with the rigors of a frigid winter season nor were many accustomed to high density urban/industrial living. The one common thread that appears to bind the complex set of motivations for Hmong resettlement is "hope for the future." Not unlike so many immigrant and refugee groups in the history of the United States, the Hmong demonstrate a firm resolve to adapt to their new society. The great challenge confronting the Hmong is to accomplish this without, in the process, breaking their traditional kinship bonds which are at the core of their identity as a people. 
In broad overview, we may conclude firstly that while public policy has attempted to encourage the geographic dispersal of Hmong across America, the kinship obligations of this group have effectively worked against this objective. Secondly, we may conclude that the pattern of Hmong secondary migration, exhibited in this paper, follows the general pattern of geographic concentration exhibited by the other Southeast Asian refugee groups but takes this pattern to a higher level. And finally, inasmuch as the Hmong continue to express a migrant as opposed to a minority orientation, the centrality of their extended family and clan obligations are likely to reinforce this resettlement pattern.

\section{Notes}

1 Nancy D. Donnelly, Changing Lives of Refugee Hmong Women (Seattle, WA: University of Washington Press, 1994).

2 For example, see Jeremy Hein, "From Migrant to Minority: Hmong Refugees and the Social Construction of Identity in the United States," Sociological Inquiry 64 (1994), 281-306.

3 David Haines, "Southeast Asian Refugees in the United States: The Interaction of Kinship and Public Policy," Anthropological Quarterly 55 (1982), 175.

4 David Haines, "Further, there is no doubt that reunion with relatives is a major factor in further moves once within the United States. Even where moves are ostensibly in search of employment, there are likely to be relatives of some kind at the place of destination," Anthropological Quarterly 55 (1982), 175.

5 Gail Paradise Kelly, "Coping with America: Refugees from Vietnam, Cambodia, and Laos in the 1970s and 1980s," Annals of the American Academy of Political and Social Science 487 (1986), 138-149.

6 Carol A. Mortland and Judy Ledgerwood, "Secondary Migration among Southeast Asian Refugees in the United States," Urban Anthropology 16 (1987), 291.

7 U.S. HR 1982a, 4.

8 Cheu Thao, "Hmong Migration in Laos and the United States," in The Hmong in the West, editors Bruce T. Downing and Douglas P. Olney (Minneapolis: Southeast Asian Refugee Studies Project/ Center for Urban and Regional Affairs at the University of Minnesota, 1982). 
Ethnic Studies Review, Vol. 19, No. 1

$9 \mathrm{Hmong}$ tradition holds that one or more of a person's souls (which may number as high as 32) may leave a person's body for a variety of reasons (e.g., fear, trauma) and when this occurs "disharmony" and "ill health" result. The shaman's job is "soul restoration" which requires that the shaman venture out into the spirit world on behalf of the afflicted party and recover the lost soul.

10Keith Quincy, Hmong: History of a People (Cheney, WA: Eastern Washington University Press, 1991), 26-55.

11 At least by any standard definition of the word "nomadic," this is so. Consider that the word derives from the Greek word nomadikos and refers "to members of a tribe, nation or race having no permanent home but moving about constantly in search of food, pasture, etc."

12This is because people are often not able to act on their "values" as they would otherwise be inclined to if certain external constraints upon their behavior were to be removed. One relevant example here is the state welfare policy which discourages a family head from working at a minimum wage level when such employment would result in approximately the same gross annual family income but with a loss of medical insurance coverage for the family. In such a case, the desire to work must be sacrificed to the desire to meet the most basic survival needs of the family.

13Neng Yang, Lee Thao, Kaying Yang, and Soua K. Yang, Introduction to Hmong History and Culture (Minneapolis: Minneapolis Public School; Collaborative Services Department, 1995), 8.

14Haines, 173.

15Teng Yang, Shoua Vang, Paoze Thao, David North, John Finck and Bruce Downing, An Evaluation of the Highland Lao Initiative: Final Report (Washington, DC: US Department of Health and Human Services, November 1985), 11.

16For example, in March, 1983, the national unemployment rate was 10.8 percent while the average rate for the studied Highland Lao Initiative sites was 11.5 percent. And by June, 1984, the national rate had dropped to 7.4 percent while these Highland Lao Initiative sites averaged 7.7 percent.

17Simon M. Faas, The Hmong in Wisconsin: On the Road to SelfSufficiency 4, No. 2 (Milwaukee:The Wisconsin Policy Research Institute, April 1991), 12. 
18This brings the total number of Hmong refugees admitted to the United States to 119,000 as of September, 1994. This figure does not include Hmong born in the United States after the arrival of their parents.

19Teng Yang, et al., 21.

20Teng Yang, et al., 28-31

21 Teng Yang, et al., 98.

22The 1990 figures are based upon the official US Census reports for that year; the 1983 figures come from ORR estimates made in 1983 which placed the number of Hmong in California at 30,000 and the number of Hmong in the United States at 58,500.

23This tradition began in the 1850 s with the early Chinese immigrants and was followed shortly by the early Japanese immigrants to the mainland of the United States.

24More exactly, 18,321 of the State total of 46,892 and unofficial agency reports indicate that this concentration has been increasing over the early first half of the 1990s.

25 The Hmong Resettlement Study/ Site Report: Fort Smith, Arkansas, 1983 (prepared for the Office of Refugee Resettlement), 14.

26By $1981 \mathrm{Hmong}$ families in Portland sponsored $76 \%$ of the incoming Hmong refugees, American mainstream families sponsored another $14 \%$, and the remaining $10 \%$ were sponsored by Church organizations

27This statistic is current with the year of 1988 .

28Few, if any, refugee Hmong could offer proof of work over this time period but California and Wisconsin took the position that these persons had worked even if they could not prove it. Also, these states took a broader view than others in allowing refugees to participate in training programs while receiving welfare and, within certain limits, to earn income from work. Robert L. Bach, "State Intervention in Southeast Asian Refugee Resettlement in the United States," Journal of Refugee Studies 1 (1988), 51-53.

29"The lure of nearby California, which had an AFDC-U program, was irresistible to many facing a future without visible means of support. April, Thousands of Hmong left the Northwest for California in the months just before and after the cutback." The Hmong Resettlement Study: Volume 
1, Final Report, Steven Reder, project director (Washington, DC: Office of Refugee Resettlement/ US Department of Health and Human Services, 1985), 47.

30The other states participating are New York, Pennsylvania, and Washington; Faas, 21-27.

31For example, the Hmong Community Survey taken in Minneapolis-St. Paul in 1982 revealed that by far the most frequent reason given for resettlement was "to be with relatives." 64 percent of the respondents gave this reason compared to 22 percent who cited educational and vocational training opportunities and only 6 percent who cited jobs; Reder, 47-48.

32Reder, 43.

33While it is true that Hmong marriage tradition requires exogamy outside of one's own clan group, it is nonetheless quite rare for marriage to occur outside the ethnic group. This custom is likely to undergo some change in America but it is one custom whose modification radically threatens the preservation of Hmong heritage.

34Jeremy Hein, States and International Migrants: Incorporation of Indochinese Refugees in the United States and France (Boulder, CO: Westview Press, 1993), 173.

35As a most recent example of this (1995) the Hmong population in North Carolina is reported to have risen to about 1,500 driven largely by prospects of farming opportunity. 